\title{
Empirical Analysis of Factors Impacting Turnover Intention among Manufacturing Workers
}

\author{
Yuting $\mathrm{Li}^{1}$, Rapinder Sawhney ${ }^{1} \&$ Guilherme Luz Tortorella ${ }^{2}$ \\ ${ }^{1}$ Industrial \& Systems Engineering, University of Tennessee, TN, USA \\ ${ }^{2}$ Department of Systems and Production Engineering, Universidade Federal de Santa Catarina, Florianópolis, \\ Brazil \\ Correspondence: Rapinder Sawhney, Industrial \& Systems Engineering, University of Tennessee, TN, USA. Tel: \\ 1-865-974-7653. E-mail: sawhney@utk.edu
}

Received: January 20, 2019

doi:10.5539/ijbm.v14n4p1
Accepted: February 22, 2019

Online Published: March 8, 2019

URL: https://doi.org/10.5539/ijbm.v14n4p1

\begin{abstract}
The purpose of this study was to investigate how turnover intention relates to job satisfaction, organizational commitment, leadership, job performance, and work-family conflict among manufacturing workers in Tennessee, USA. A causal model was proposed, and a turnover intention survey questionnaire for manufacturing workers was developed. The data were collected from manufacturing companies in the Tennessee area and analyzed by SPSS and structural equation modeling (SEM). The results of our study indicated that job satisfaction and organizational commitment negatively and significantly affected manufacturing workers' turnover intentions, while work-family conflict positively and significantly affected turnover intentions. Although leadership indirectly influenced turnover intention, its effects on turnover intention were fully mediated by job satisfaction and organizational commitment. No effect of job performance on turnover intention was found in this study with manufacturing workers. The results suggested that policies for enhancing worker job satisfaction and organizational commitment, balancing work-family conflict, and improving leadership style should be proposed to reduce turnover intention.
\end{abstract}

Keywords: Job Satisfaction, Organizational Commitment, Leadership, Job Performance, Work-Family Conflict, and Turnover Intention

\section{Introduction}

Employee turnover has been studied by management scholars and practitioners for many decades, and it remains a critical issue of widespread interest for organizations and managers (Allen, Bryant, \& Vardaman, 2010). Employee turnover refers to workers who leave their organization and are replaced by new employees. Employee turnover consists of voluntary turnovers, such as resignation, quitting or retirement, and involuntary turnovers, such as termination, discharge, layoff or death. A high employee turnover rate has become a severe problem in American society. According to a recently released survey, the voluntary turnover rate of all industries has increased from $9.1 \%$ in 2011 to $12.8 \%$ in 2016, and the total turnover rate of all industrial industries has increased from $14.4 \%$ in 2011 to $17.8 \%$ in 2016 (Bares, 2016). For organizations, the high voluntary turnover rate has more disadvantages than advantages. The first mainly negative effects of employee turnover are the potentially high costs associated with replacing a departed employee. The costs associated with recruiting, selecting, and training new employees are always very high, so organizations always want to increase their skilled employees' commitment and improve their skilled employees' retention. The second highly impactful negative effects of employee turnover are the disruption of organizational function, such as decreased performance and unfulfilled daily functions.

It is apparent that employee turnover is costly for an organization; thus, reducing employee turnover rates is essential for human resource personnel and managers. To reduce employee turnover rates and save money for the organization, the primary goal is to determine the typical reasons employees decide to leave the organization. Based on the literature review, turnover intention is always influenced by various factors, such as job satisfaction, organizational commitment, leadership, job performance, work-family conflict, pay, promotion, workload, and absenteeism. It was unnecessary and impractical to study every factor of turnover intention derived from the literature review. Instead, a short list of factors was selected by using the criteria of popularity, independence, 
measurability, significance and practicability. Thus, job satisfaction, organizational commitment, leadership, job performance, and work-family conflict were selected as predictive factors for manufacturing worker's turnover intention.

Job satisfaction has been considered the most crucial factor for turnover intention for many decades (Jamal, 1997). Most researchers have reported that job satisfaction and turnover intention are negatively related (DeConinck \& Stilwell, 2004). However, the opposite opinion also exists; for example, Gu et al. (Gu et al., 2006) reported that there is no significant relationship between job satisfaction and turnover intention. As another significant predictor of turnover intention, organizational commitment has also been widely researched and measured in many different ways. The concept of organizational commitment was first proposed by Becker (Becker, 1960) around the beginning of the 1960s and by the studies developed by Allen et al. (Allen \& Meyer, 1990) with three-component theory in the 1990s, namely, affective commitment, continuous commitment, and normative commitment. The point that organizational commitment negatively influences turnover intention, which means that employees with stronger organizational commitment are less likely to leave the organization, was also confirmed by many scholars (Meyer, Stanley, Herscovitch, \& Topolnytsky, 2002; Wu \& Polsaram, 2013). Leadership has also been identified in previous studies as producing a significant negative impact on employees' turnover intention (Bycio, Hackett, \& Allen, 1995; Martin \& Epitropaki, 2001). A study conducted by Ryan and Todd (Ryan \& Todd, 2009) concluded that employees' job performance negatively affects turnover intention. Work-family conflict is defined as 'a form of inter-role conflict that will appear when it is difficult to balance the pressure of work and family' (Greenhaus \& Beutell, 1985). Some studies reported that work-family conflict could positively affect turnover intention (Blomme, Rheede, \& Tromp, 2010), whereas some studies reported that there is neither direct nor indirect relationships between work-family conflict and turnover intention (Post, DiTomaso, Farris, \& Cordero, 2009).

To date, there has been no research on turnover intention among manufacturing workers. It is essential to examine the possible factors that influence manufacturing workers' turnover intention. Thus, the purpose of this paper is to identify the main predictors of manufacturing workers' turnover intention and explore the relationship between turnover intention and these predictors, such as job satisfaction, organizational commitment, leadership, job performance, and work-family conflict.

\section{Literature Review}

\subsection{Turnover Intention}

The study of turnover has received considerable attention from both academics and managers since the beginning of the 20th century, and several thousand publications on qualitative and quantitative investigations of turnover have been published since then (Muchinsky \& Morrow, 1980; Griffeth, Hom, \& Gaertner, 2000). In the 21 st century, turnover research continues to command widespread attention (Hom, 2011). The root reason for this interest is that turnover leads to increased financial cost (Allen, Bryant, \& Vardaman, 2010), disrupts organizational function and operations (Ton \& Huckman, 2008), increases accident rates (Shaw, Gupta, \& Delery, 2005), and decreases customer service and quality (Hancock, Allen, Bosco, McDaniel, \& Pearce, 2013).

Over the years, scholars and researchers have proposed numerous definitions to better understand turnover intention. According to Tett and Meyer, turnover intention is defined as 'a conscious and deliberate willfulness to leave the organization' (Tett \& Meyer, 1993). Glissmeyer (Glissmeyer, 2012) suggested that turnover intention should be defined as 'the mediating factor between attitudes affecting the intent to quit and actually quitting an organization.' Due to the purpose of this research, turnover intention is defined as 'the degree to which an organizational member believes he or she would terminate his or her position at some unspecified time in the future' (Hinshaw, Smeltzer, \& Atwood, 1987).

\subsection{Job Satisfaction}

There are many factors, such as job strain, job satisfaction, organizational commitment, and income, that could affect turnover intention in various ways. However, job satisfaction was one of the earliest proposed and frequently mentioned influencing factors and has been considered one of the most critical factors in predicting turnover intention (Jamal, 1997; Gu et al., 2006). According to Bright (Bright, 2008), job satisfaction and turnover intention are reflections of the outlook, which is influenced by the degree to which employees' salient needs are satisfied by their work, that employees have about their employment.

A negative association between job satisfaction and turnover intention has been consistently reported by researchers. By investigating 480 extension agents with less than six years of employment, representing 12 states in the southern United States, Michael and Eric (Michael \& Eric, 2013) stated that there is a strong and negative 
relationship ( $r=-.619, p=.000$ ) between job satisfaction and intent to quit. Chieh and Gursoy (Chieh \& Gursoy, 2016) suggested a significant negative relationship between job satisfaction and turnover intention $(r=-.55, p$ $<.01)$ based on their investigation results using data collected from employees of a midscale chain hotel.

Job satisfaction also affects employees' job performance. Chao et al. (Chao, Jou, Liao, \& Kuo, 2015) used a cross-sectional structured questionnaire to collect data from 344 licensed professionals in a Taiwan rural regional hospital and the results showed a positive correlation between job satisfaction and job performance $(\beta=.18, t=$ 3.06). Hence, the higher job satisfaction was, the greater the likelihood of higher job performance.

There is published evidence of a strong positive correlation between job satisfaction and organizational commitment (Gregson, 1992). Based on the results of an analysis of two datasets, Gregson (Gregson, 1992) concluded that a significant positive relationship exists between job satisfaction and organizational commitment and that both variables should be included in models that predict turnover intention. Thus, employees with higher job satisfaction tend to have higher organizational commitment.

Hypothesis 1 (H1): Manufacturing workers' job satisfaction has a significant negative effect on their turnover intention.

Hypothesis 2 (H2): Manufacturing workers' job satisfaction has a significant positive effect on their job performance.

Hypothesis 3 (H3): Manufacturing workers' job satisfaction has a significant positive effect on their organizational commitment.

\subsection{Organizational Commitment}

Organizational commitment has become an essential topic for organizational research because it is conceived of as a crucial variable in the literature associated with turnover intention (Somers, 1993; Omar, Anuar, Majid, \& Johari, 2012). Due to the high costs associated with employee turnover, understanding the relationship between organizational commitment and turnover intention may prove extremely important and useful for scholars and managers (Schwepker, 1999).

Based on some research findings, it is not difficult to confirm that organizational commitment has a significant negative impact on turnover intention. Using a sample of 172 employees from across organizations in Malaysia, Ponnu and Chuah (Ponnu \& Chuah, 2010) stated that a significant negative relationship exists between organizational commitment and turnover intention $(r=-.715, p<.01)$. The similar research conducted by Michael and Eric (Michael \& Eric, 2013) indicated that there is also a strong and negative relationship between organizational commitment and intent to quit $(r=-.652, p=.000)$. Hence, employees with a stronger commitment to the organization will usually exhibit lower turnover intentions. In other words, a sense of commitment develops, which in turn may lead to the intention to stay with the organization when employees feel happy at work.

Hypothesis 4 (H4): Manufacturing workers' organizational commitment has a significant negative impact on their turnover intentions.

\subsection{Job Performance}

The potential linkage between work performance and turnover intention was considered in earnest in the 1930s, and an association between work performance and turnover intention has been reported in many kinds of literature (Judge \& Bono, 2001). However, Poon (Poon, 2004) and Podsakoff et al. (Podsakoff, J. Lepine, \& M. Lepine, 2007) stated that the potential relationship between work performance and turnover intention remains unsystematic and limited, even if the various determinants of work performance have been identified. Cropanzano et al. (Cropanzano, Rupp, \& Byrne, 2013) have shown that an employee with higher work performance and tends to have weaker turnover intention; therefore, employees who leave the organization exhibit poor work performance before resignation. Based on research that has demonstrated and argued that high performers tend to receive higher rewards, Joseph et al. (Joseph, Kok-Yee, Koh, \& Ang, 2007) stated that work performance should be negatively related to turnover intention through enhanced job satisfaction.

Hypothesis 5 (H5): Manufacturing workers' job performance has a significant negative impact on their turnover intention.

\subsection{Leadership}

Leadership is also a primary factor that can affect employees' turnover intentions, and the relationship between the two has been explored by some researchers, such as Bass (Bass, 1990), Bycio et al. (Bycio et al., 1995) and Martin (Martin \& Epitropaki, 2001). Bass (Bass, 1990) stated that leadership could highly affect turnover 
intention and showed that transformational leadership is the critical variable in reducing and mitigating turnover intentions. In the studies undertaken by Bycio et al. (Bycio et al., 1995) in the nursing profession, it was found that higher degrees of transformational leadership are associated with lower intentions to leave. Based on the study among employees of several commercial and profit-oriented-based businesses, Martin and Epitropaki (Martin \& Epitropaki, 2001) discovered that transformational leadership has a significant negative effect on turnover intentions.

An impact of leadership on job satisfaction has also been found in many industries. Raimonda and Modesta (Raimonda \& Modesta, 2016) investigated the relationship between different styles of leadership and job satisfaction by using 72 faculty members and ten supervisors from Lithuanian public and private universities. The results revealed that the controlling autocrat leadership style $(r=.626, p<.01)$ had the smallest positive and significant impact on job satisfaction, while the servant leadership style $(r=.731, p<.01)$ had the greatest impact. McCutcheon et al. (McCutcheon, Doran, Evans, McGillis, \& Pringle, 2009) conducted a study of more than 700 nurses from seven Canadian teaching and community hospitals and found positive effects of transformational leadership behaviors among nurse managers on job satisfaction.

Previous researchers have also demonstrated that different leadership styles have an impact on the level of organizational commitment. Dale and Fox (Dale \& Fox, 2008) conducted a study that encompassed 147 full-time employees from a large manufacturing corporation located in the Midwest. The results indicated that the leader initiating $(\beta=.17, p<.05)$ and leader consideration $(\beta=.42, p<.05)$ styles were positively related to organizational commitment.

Hypothesis 6 (H6): Leadership has a significant negative effect on manufacturing workers'turnover intentions.

Hypothesis 7 (H7): Leadership has a significant positive impact on manufacturing workers' job satisfaction.

Hypothesis 8 (H8): Leadership has a significant positive impact on manufacturing workers' organizational commitment.

\subsection{Work-Family Conflict}

Work-family conflict refers to "a form of inter-role conflict in which the general demands of time devoted to and strain created by the job, interfere with performing family-related responsibilities" (Greenhaus \& Beutell, 1985). Many findings have been reported by researchers about the relationship between work-family conflict and employee turnover intention. (Karatepe \& Baddar, 2006; Ahuja, Chudoba, Kacmar, McKnight, \& George, 2007; Blomme et al.,2010). These researchers suggested that there is a significant positive relationship between work-family conflict and turnover intention; in other words, if work-family conflict increases, then an elevated level of turnover intention would follow.

Karatepe and Baddar (Karatepe \& Baddar, 2006) investigated frontline employees in the Jordanian hotel industry and found that work-family conflict was positively related to frontline employees' turnover intention $(r=.43, p$ $=.001$ ). Similarly, an investigation conducted by Blomme et al. (Blomme et al., 2010) found that both work-family conflict and organizational support are predictors of employee turnover intention in the hospitality industry. Ahuja et al. (Ahuja et al., 2007) suggested that work-family conflict is a crucial source of stress among IT road warriors, who are susceptible to work-family conflict issues, that may lower their organizational commitment and, as a result, is a potential antecedent to their turnover intention. Thus, employees who have higher work-family conflict are prone to have a higher intention to leave the organization.

Previous research has also shown that work-family conflict negatively affects job satisfaction (Cortese, Colombo, \& Ghislieri, 2010; Armstrong Atkin-Plunk, \& Wells, 2015). In Italy, Cortese et al. (Cortese et al., 2010) conducted a descriptive correlational study to explore the causal relationship between work-family conflict and job satisfaction among 351 professional nurses. The results demonstrated that work-family conflict correlated negatively with job satisfaction $(r=-.40, p<.01)$. Armstrong et al. (Armstrong et al., 2015) divided work-family conflict into three specific domains and examined them in relation to job satisfaction in a diverse sample of 441 correctional officers employed at 13 public adult correctional facilities. The results indicated that work-family conflict-time $(r=-.35, p<.01)$, work-family conflict-strain $(r=-.48, p<.01)$ and work-family conflictbehavior $(r=-.28, p<.01)$ were all significantly related to job satisfaction. Thus, the presence of work-family conflict contributes to decreased levels of employee job satisfaction.

Hypothesis 9 (H9): Work-family conflict has a significant positive effect on manufacturing workers' turnover intentions.

Hypothesis 10 (H10): Work-family conflict has a significant negative impact on manufacturing workers' job satisfaction. 


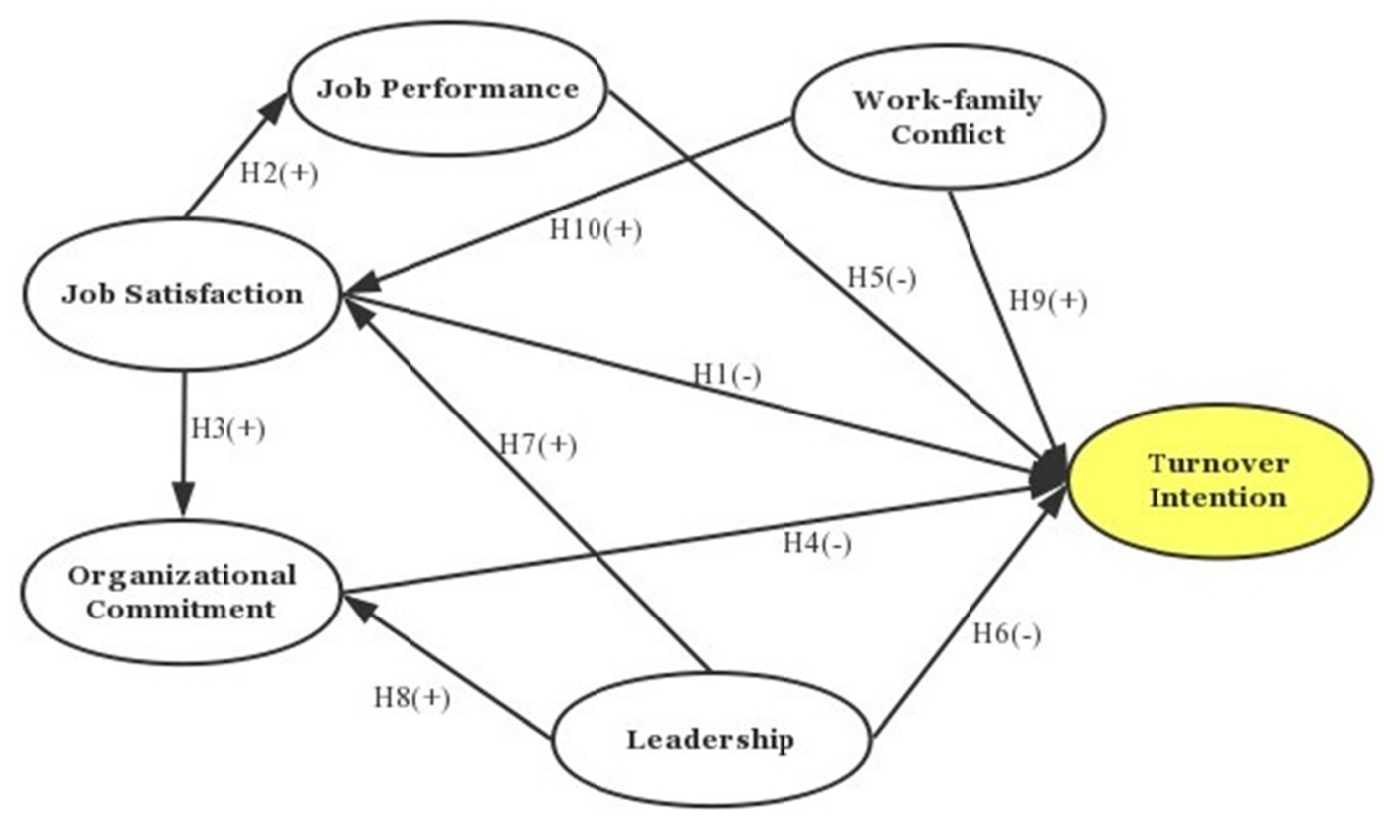

Figure 1. The conceptual framework of this study

\section{Methods}

\subsection{Samples and Sampling Procedures}

A target population can be loosely defined as 'the total collection of all members, cases or elements about which the researcher wishes to draw conclusions' (Huysamen, 1994). Defining the target population clearly is necessary because the data will lose value if the wrong sample population is targeted. The sample population for this survey included manufacturing workers from different organization sites in the Tennessee area because Tennessee is a typical manufacturing state. According to a report from the Tennessee Department of Labor \& Workforce Development, there were approximately 266,090 employed manufacturing workers, representing 9.13\% of total employment, in Tennessee in May 2017.

Sample size requirements remain a vexing problem in structural equation modeling (SEM)-based studies, even though SEM approaches have been developed in recent decades. However, compared to traditional approaches, the partial least squares (PLS)-SEM method places less emphasis on the sample size requirement. The PLS-SEM algorithm does not compute all relationships in the structural model at the same time. Instead, it uses ordinary least squares (OLS) regressions to estimate the model's partial regression relationships. For the purpose of this study, the often-cited ' 10 times rule' (Barclay et al., 1995) is applied, and the sample size is determined by 1) 10 times the largest number of formative indicators used to measure a single construct or 2) 10 times the largest number of structural paths directed at a particular construct in the structural model.

The conceptual model presented in Figure 1 is constructed of 'Turnover Intention' and five formative indicators; thus, the 10 times the largest number of formative indicators used to measure a single construct indicates that 5 * $10=50$ represents the minimum number of observations needed to estimate the PLS-SEM model.

\subsection{Demographics and General Profile}

The sample population in this study included manufacturing workers who were working in manufacturing organizations in the Tennessee area. We distributed the paper-based turnover intention survey questionnaires to 180 workers through the administrative departments of the manufacturing companies in February 2018. After four months, 147 surveys $(81.7 \%)$ were returned, but only 138 responses were validl. Table 1 presents the frequencies among respondents with regard to their gender, race, age, length of service, salary range and job group.

As shown in Table 1, 86.2\% of the respondents were male, and 13.8\% were female. Almost half (53.6\%) of the respondents stated that they were under 40 years of age. Approximately half (47.8\%) of the total respondents 
worked in the organization for less than two years, and $15.9 \%$ of the respondents worked in their organization for approximately 3-5 years. Approximately $21 \%$ of the respondent state that they had an annual salary less than $\$ 30,000$, and more than half $(53.6 \%)$ of the respondents had an annual salary between $\$ 30,001$ and $\$ 40,000$. Approximately $16.7 \%$ of the respondents were team leaders and had a higher position in the organization.

Table 1. Table of frequencies of demographic information

\begin{tabular}{|c|c|c|c|c|c|}
\hline Gender & & Frequency & Percent & Valid Percent & Cumulative Percent \\
\hline \multirow[t]{3}{*}{ Valid } & Female & 19 & 13.8 & 13.8 & 13.8 \\
\hline & Male & 119 & 86.2 & 86.2 & 100.0 \\
\hline & Total & 138 & 100.0 & 100.0 & \\
\hline \multicolumn{6}{|l|}{ Age } \\
\hline \multirow[t]{7}{*}{ Valid } & Under 21 & 20 & 14.5 & 14.5 & 14.5 \\
\hline & $22-25$ & 19 & 13.8 & 13.8 & 28.3 \\
\hline & $26-30$ & 12 & 8.7 & 8.7 & 37.0 \\
\hline & $31-40$ & 23 & 16.7 & 16.7 & 53.6 \\
\hline & $41-50$ & 41 & 29.7 & 29.7 & 83.3 \\
\hline & 51 or more & 23 & 16.7 & 16.7 & 100.0 \\
\hline & Total & 138 & 100.0 & 100.0 & \\
\hline \multicolumn{6}{|c|}{ Length of service } \\
\hline \multirow[t]{7}{*}{ Valid } & Less than 1 year & 33 & 23.9 & 23.9 & 23.9 \\
\hline & $1-2+$ & 33 & 23.9 & 23.9 & 47.8 \\
\hline & $3-5+$ & 22 & 15.9 & 15.9 & 63.8 \\
\hline & $6-10+$ & 15 & 10.9 & 10.9 & 74.6 \\
\hline & $11-20+$ & 20 & 14.5 & 14.5 & 89.1 \\
\hline & 21 or more & 15 & 10.9 & 10.9 & 100.0 \\
\hline & Total & 138 & 100.0 & 100.0 & \\
\hline \multicolumn{6}{|c|}{ Salary range } \\
\hline \multirow[t]{7}{*}{ Valid } & Under $\$ 30,000$ & 29 & 21.0 & 21.0 & 21.0 \\
\hline & $\$ 30,001-\$ 40,000$ & 74 & 53.6 & 53.6 & 74.6 \\
\hline & $\$ 40,001-\$ 50,000$ & 21 & 15.2 & 15.2 & 89.8 \\
\hline & $\$ 50,001-\$ 75,000$ & 6 & 4.3 & 4.3 & 94.2 \\
\hline & $\$ 75,001-\$ 100,000$ & 5 & 3.6 & 3.6 & 97.8 \\
\hline & More than $\$ 100,000$ & 3 & 2.2 & 2.2 & 100.0 \\
\hline & Total & 138 & 100.0 & 100.0 & \\
\hline \multicolumn{6}{|c|}{ Job group } \\
\hline \multirow[t]{6}{*}{ Valid } & Team Member & 115 & 83.3 & 83.3 & 83.3 \\
\hline & Team Leader & 10 & 7.2 & 7.2 & 90.5 \\
\hline & Area Coordinator & 2 & 1.4 & 1.4 & 92.0 \\
\hline & Office Group/Sales Rep & 7 & 5.1 & 5.1 & 97.1 \\
\hline & Manager & 4 & 2.9 & 2.9 & 100.0 \\
\hline & Total & 138 & 100.0 & 100.0 & \\
\hline
\end{tabular}

\subsection{Instruments}

The job satisfaction measure was adapted from Spector's (Spector, 1994) Job Satisfaction Survey, which can evaluate workers' attitudes concerning aspects of their jobs. To reduce the workload of the participants in our study, we used five measures of organizational commitment developed by Meyer and Allen (Jaros, 2007), which have been tested and validated mainly in the United States of America (Lee \& Gao, 2005). Four measures of leadership were also derived from Spector (Spector, 1994). The work-family conflict measure was developed by Netemeyer et al. (Netemeyer, Boles, \& McMurrian, 1996) to measure the work-to-family conflict of employees. A job performance instrument was adopted from Koopmans et al. (Koopmans et al., 2013) to measure workers perceived individual work performance. The turnover intention survey questionnaire was adopted from Lambert and Hogan (Lambert \& Hogan, 2009) and was developed to measure employees' intentions to leave or stay with the organization. A pilot study was conducted to test the reliability and validity of each item of the survey questionnaire, and all the items were retained due to the favorable results. 


\section{Results}

\subsection{Correlation}

Table 2. Correlations between constructs

\begin{tabular}{|c|c|c|c|c|c|c|}
\hline Variables & JS & $\mathrm{OC}$ & LEA & WFC & JP & TUI \\
\hline Job Satisfaction (JS) & 1.000 & & & & & \\
\hline $\begin{array}{l}\text { Organizational Commitment } \\
\text { (OC) }\end{array}$ & $0.789 * * *$ & 1.000 & & & & \\
\hline Leadership (LEA) & $0.641 * * *$ & $0.628 * * *$ & 1.000 & & & \\
\hline Work-Family Conflict (WFC) & $-0.541 * * *$ & $-0.550 * * *$ & $-0.542 * * *$ & 1.000 & & \\
\hline Job Performance (JP) & $0.503 * * *$ & $0.530 * * *$ & $0.505 * * *$ & $-0.379 *$ & 1.000 & \\
\hline Turnover Intention (TUI) & $-0.729 * * *$ & $-0.697 * * *$ & $-0.475^{* * *}$ & $0.602 * * *$ & -0.351 & 1.000 \\
\hline
\end{tabular}

To examine the relationship among job satisfaction, organizational commitment, leadership, work-family conflict, job performance, and turnover intention, canonical correlation coefficient methods were used to compute the correlations and the strength of different variables. Table 2 displays the correlations among all of these variables in the model. With only a few exceptions, job satisfaction, organizational commitment, leadership, and job performance have a negative relationship with work-family conflict and turnover intention. Moreover, job satisfaction and organizational commitment are strongly, negatively related to turnover intention, and work-family conflict is strongly, positively related to turnover intention.

\subsection{Model Evaluation}

An SEM path analysis technique was employed to test the hypothesized relationships between the independent and dependent variables. The factor loading for each item and the elimination of individual items from the model processed by the preliminary factor analysis are shown in Table 3. According to some previous studies (Tabachnick \& Fidell, 2007), factor loading values at 0.32 or greater are considered acceptable, whereas those greater than 0.55 are considered good. Table 3 shows that the smallest factor loading is 0.576 . Thus, all the loading values of the items to the corresponding dimensions are greater than 0.55 , illustrating that the construct validity of the survey questionnaire was good. A reliability and validity test of the constructs was performed after the preliminary factor analysis, and the results are shown in the following subsections. 
Table 3. Factor loading for each item

\begin{tabular}{|c|c|c|c|c|c|c|c|}
\hline & & JS & $\mathrm{OC}$ & LEA & WFC & JP & TUI \\
\hline \multirow[t]{4}{*}{ JS } & Pride of job & 0.791 & & & & & \\
\hline & Enjoyable job & 0.808 & & & & & \\
\hline & Job is meaningless & 0.697 & & & & & \\
\hline & Satisfied with job & 0.840 & & & & & \\
\hline \multirow[t]{5}{*}{$\mathrm{OC}$} & Happy being a member of the organization & & 0.819 & & & & \\
\hline & Not feeling of belonging to the organization & & 0.576 & & & & \\
\hline & Loyal to the organization & & 0.600 & & & & \\
\hline & Owe this organization & & 0.807 & & & & \\
\hline & The organization deserves loyalty & & 0.828 & & & & \\
\hline \multirow[t]{4}{*}{ LEA } & Competent & & & 0.839 & & & \\
\hline & Good relationship & & & 0.870 & & & \\
\hline & Helpful & & & 0.884 & & & \\
\hline & Unfair & & & 0.826 & & & \\
\hline \multirow[t]{3}{*}{ WFC } & Work interferes with home and family & & & & 0.926 & & \\
\hline & Cannot fulfill family responsibilities & & & & 0.930 & & \\
\hline & Work-related duties change family plans & & & & 0.870 & & \\
\hline \multirow[t]{4}{*}{ JP } & Work is satisfied & & & & & 0.838 & \\
\hline & Work was done on time & & & & & 0.777 & \\
\hline & Shows initiative in the work & & & & & 0.845 & \\
\hline & Fulfills the responsibilities & & & & & 0.831 & \\
\hline \multirow[t]{5}{*}{ TUI } & Looking for a new job recently & & & & & & 0.871 \\
\hline & Looking for a new job when enrolled & & & & & & 0.854 \\
\hline & Thought of quitting frequently & & & & & & 0.875 \\
\hline & Thought of switching current job & & & & & & 0.872 \\
\hline & The desire to leave current job & & & & & & 0.832 \\
\hline
\end{tabular}

\subsubsection{Measurement Model Analysis (Outer Model)}

\section{Reliability analysis}

The reliability of instruments was estimated by means of the internal consistency, which by evaluating the within-scale consistency of the responses to the items of the measure. Cronbach's alpha is the most widely used method for estimating the internal consistency, and it is assessed using 0.7 as the cutoff point criterion. All constructs in the turnover intention model demonstrated sufficient levels of internal consistency reliability, as shown in Table 4. The Cronbach's alpha values ranged from 0.781 for 'Organizational Commitment' to 0.913 for 'Turnover Intention'. Composite reliability is also a convenient and sufficient test used to examine internal consistency, which, according to the general rule of thumb, should be greater than 0.7 to be considered adequate. The composite reliability values estimated for each of the constructs ranged from 0.851 (Organizational Commitment) to 0.935 (Turnover Intention) and are listed in Table 4. Cronbach's alpha assumes unidimensionality, and the items are equally related to the construct and are, therefore, interchangeable. However, composite reliability takes into consideration the varying factor loading of each item. Therefore, the more factor loadings fluctuate among items, the higher the discrepancy between the values of Cronbach's alpha and composite reliability. All the values obtained from the Cronbach's alpha and composite reliability indicate that the variables in this study have a satisfactory level of internal consistency. 
Table 4. Internal consistency reliability of survey instrument

\begin{tabular}{lccc}
\hline & Cronbach's Alpha & Composite Reliability & Average Variance Extracted (AVE) \\
\hline Work-Family Conflict & 0.894 & 0.934 & 0.826 \\
Job Performance & 0.842 & 0.894 & 0.678 \\
Job Satisfaction & 0.792 & 0.865 & 0.618 \\
Leadership & 0.878 & 0.916 & 0.731 \\
Organizational Commitment & 0.781 & 0.851 & 0.540 \\
Turnover Intention & 0.913 & 0.935 & 0.741 \\
\hline
\end{tabular}

\section{Convergent validity}

Convergent validity essentially refers to the degree of similarity between the scores of the two instruments that are supposed to measure the same concept. Therefore, a relatively high correlation between the two instruments should be expected. In this study, internal consistency convergent validity is assessed using indicator reliability (factor loading) and average variance extracted (AVE). A 0.50 cutoff criterion for convergent validity was considered acceptable for all the constructions. As shown in Table 4, the AVE values range from 'Organizational Commitment' with a value of 0.540 to 'Work-Family Conflict' with a value of 0.826 . These values indicate that all variables have an acceptable level of convergent validity. In other words, a construct converges or shares a high proportion of variance formed from all of the items.

\section{Discriminant validity}

Discriminant validity refers to the scores of the two instruments that are supposed to measure a related but different concept. Discriminant validity in this study was assessed using the Fornell-Larcker criterion analysis by comparing the square roots of the AVEs for two latent variables and their intercorrelations. The correlation matrix, which includes the correlation between variables in the lower left off-diagonal elements, and the square root of the AVE along the diagonal are shown in Table 5. The results imply adequate discriminant validity because all the diagonal elements are greater than any other element in the corresponding row and column.

Table 5. Discriminant validity

\begin{tabular}{|c|c|c|c|c|c|c|}
\hline & WFC & JP & JS & LEA & $\mathrm{OC}$ & TUI \\
\hline Work-Family Conflict & 0.909 & & & & & \\
\hline Job Performance & -0.337 & 0.823 & & & & \\
\hline Job Satisfaction & -0.470 & 0.405 & 0.786 & & & \\
\hline Leadership & -0.504 & 0.370 & 0.576 & 0.855 & & \\
\hline Organizational Commitment & -0.449 & 0.398 & 0.730 & 0.577 & 0.735 & \\
\hline Turnover Intention & 0.546 & -0.260 & -0.678 & -0.412 & -0.645 & 0.861 \\
\hline
\end{tabular}

\subsubsection{Structural Model Analysis (Inner Model)}

The construct measures are reliable and valid and have been confirmed in the previous section. We will continue to address the assessment of the structural model results in this section. Six variables were derived from the measurement model analysis. The key criteria for assessing the structural model, such as path coefficients, the coefficient of determination $R^{2}$, effect size $f^{2}$ and the predictive relevance $Q^{2}$, are examined in the following sections.

\section{Collinearity assessment}

Table 6. Collinearity assessment

\begin{tabular}{lcccc}
\hline \multirow{2}{*}{ Predictor } & \multicolumn{3}{c}{ VIF } & JP \\
\cline { 2 - 5 } & JS & OC & 1.000 & 2.095 \\
\hline Job Satisfaction & & 2.101 & & 2.244 \\
Organizational Commitment & & & & 1.596 \\
Leadership & 1.882 & 1.876 & 1.124 \\
Job Performance & & & & 1.145 \\
Work-Family Conflict & 4.010 & & & \\
\hline
\end{tabular}

The collinearity issue is that any indicator exhibits high intercorrelations or interassociations with other 
indicators in the same construct. Collinearity can result in several problems, such as variation inflation issues or unstable and unreliable regression estimates. Normally, collinearity can be measured by variance inflation factors (VIF) and tolerance. The SmartPLS results in Table 6 show that all the VIF values for all the predictor constructions were clearly below the threshold value of 5 . The predictor variable of 'Work-Family Conflict' to a latent variable of 'Job Satisfaction' had the highest VIF value of 4.010. Therefore, it is concluded that collinearity is absent among predictors in the structural model.

\section{Path coefficients}

The path coefficients explain how strong the effect of one variable is on another variable, and the weight of different path coefficients enables us to rank their relative statistical importance. The range of the standardized path coefficient value is from -1 , which represents the strong negative relationship between constructs, to 1 , which represents the strong positive relationship between constructs. The estimates of the path coefficients, which represent the hypothesized relationships among the constructs, are obtained for the structural model relationships after running the PLS-SEM algorithm. The significance of the path coefficients is determined by the $p$-value, which is calculated using the bootstrapping method. The estimated path coefficients and the significance level are shown in Figure 2 and Table 8. Comparing the relative importance of factors that affect 'Turnover Intention', it is observed that 'Job satisfaction', 'Organizational Commitment' and 'Work-Family Conflict' were most important. Additionally, 'Leadership' and 'Work-Family Conflict' significantly impact 'Job Satisfaction', and 'Job Satisfaction' significantly impacts 'Organizational Commitment'.

The coefficient of determination $R^{2}$

The coefficient of determination is a statistical measure of how well the regression predictions approximate the actual data values. It is used to measure the amount of variance explained by the model, which represents the combined effect of independent latent variables on the dependent latent variable and is calculated as the square of the correlation coefficient $(r)$ between the sample and predicted data. The $R^{2}$ value ranges from 0 to one, where values closer to 0 represent a poor fit while values closer to 1 represent a perfect fit. The $R^{2}$ values for 'Turnover Intention', 'Job Satisfaction' and 'Organizational Commitment' are 0.574, 0.375 and 0.570, respectively. However, the coefficient of determination $R^{2}$ for 'Job Performance' is only 0.164 . This result illustrates that the model moderately fits the data, as in the behavior studies and the complexity model.

\section{Effect size $f^{2}$}

To evaluate whether the omitted construct has a substantive impact on the endogenous constructs, Cohen (Cohen, 1988) defined an effect size $f^{2}$ that represents the change in $R^{2}$ value when a specified exogenous construct is omitted from the model. The effect size $f^{2}$ of all the predicting constructs was also obtained after running the PLS-SEM algorithm, as shown in Table 7. It is easily observed that 'Job Satisfaction', 'Organizational Commitment' and 'Work-Family Conflict' have an above medium effect size, indicating that these variables are the influential factors affecting 'Turnover Intention'. Therefore, the organization must pay special attention to the manufacturing worker's job satisfaction, organizational commitment, and work-family balance.

Table 7. Effect size $f^{2}$

\begin{tabular}{lcccc}
\hline \multirow{2}{*}{ Predictor } & \multicolumn{3}{c}{ Effect Size $f^{2}$} \\
\cline { 2 - 5 } & JS & OC & JP & TUI \\
\hline Job Satisfaction & & 0.300 & 0.090 & 0.149 \\
Organizational Commitment & & & & 0.125 \\
Leadership & 0.025 & 0.029 & 0.015 \\
Job Performance & & & 0.001 \\
Work-Family Conflict & 0.000 & & & 0.110 \\
\hline
\end{tabular}

\section{Predictive relevance $Q^{2}$}

In addition to evaluating the structural model, the Stone-Geisser $Q^{2}$ value (Geisser, 1974; Stone, 1974) should be examined to determine the model's predictive relevance, which accurately predicts the data points of indicators in reflective measurement models of endogenous constructs and endogenous single-item constructs. A $Q^{2}$ value greater than zero for a certain reflective endogenous latent variable indicates the path model's predictive relevance for the particular construct. The predictive relevance $Q^{2}$ values were obtained after conducting the blindfolding procedure. The results show that the $Q^{2}$ values for 'Job Performance', 'Job Satisfaction', 'Organizational Commitment', and 'Turnover Intention' were 0.035, 0.254, 0.294 and 0.373, respectively. 
Therefore, the path model has predictive relevance because all of the $Q^{2}$ values are greater than zero based on the criterion.

\subsection{Hypothesis Testing}

Confirmatory factor analysis was used to evaluate the research model, and SEM was used to test the proposed hypothesis, as shown in Figure 2. Ten hypotheses were postulated and tested to investigate the relationships between Turnover Intention and its antecedents: Job Satisfaction, Organizational Commitment, Leadership, Work-Family Conflict and Job Performance. The results reported in Figure 2 and Table 8 provide support for six hypotheses (H1, H3, H4, H7, H9 and H10) and reject four hypotheses (H2, H5, H6 and H8). Those hypotheses that were supported are significant at a confidence level of $p<.001, .01$ or .05 .

Table 8. Path model and hypothesis testing for Turnover Intention

\begin{tabular}{llllll}
\hline \multicolumn{1}{c}{ Hypothesis } & \multicolumn{1}{c}{$\begin{array}{c}\text { Proposed hypothesis } \\
\text { relationship }\end{array}$} & $\begin{array}{c}\text { Positive or } \\
\text { negative }\end{array}$ & $\begin{array}{c}\text { Estimate } \\
\text { results }\end{array}$ & \multicolumn{1}{c}{ Pesults } \\
\hline H1 & JS $\rightarrow$ TUI & - & -0.415 & $0.023^{*}$ & Significant \\
H2 & JS $\rightarrow$ JP & + & 0.405 & 0.079 & Nonsignificant \\
H3 & JS $\rightarrow$ OC & + & 0.596 & $0.000^{* * *}$ & Significant \\
H4 & OC $\rightarrow$ TUI & - & -0.315 & $0.000^{* * *}$ & Significant \\
H5 & JP $\rightarrow$ TUI & - & 0.088 & 0.743 & Nonsignificant \\
H6 & LEA $\rightarrow$ TUI & - & 0.129 & 0.450 & Nonsignificant \\
H7 & LEA $\rightarrow$ JS & + & 0.455 & $0.001^{* *}$ & Significant \\
H8 & LEA $\rightarrow$ OC & + & 0.234 & 0.067 & Nonsignificant \\
H9 & WFC $\rightarrow$ TUI & + & 0.304 & $0.047^{*}$ & Significant \\
H10 & WFC $\rightarrow$ JS & - & -0.241 & $0.003^{* *}$ & Significant \\
\hline
\end{tabular}

* Significant at $p<.05$

$* *$ Significant at $p<.01$

$* * *$ Significant at $p<.001$.

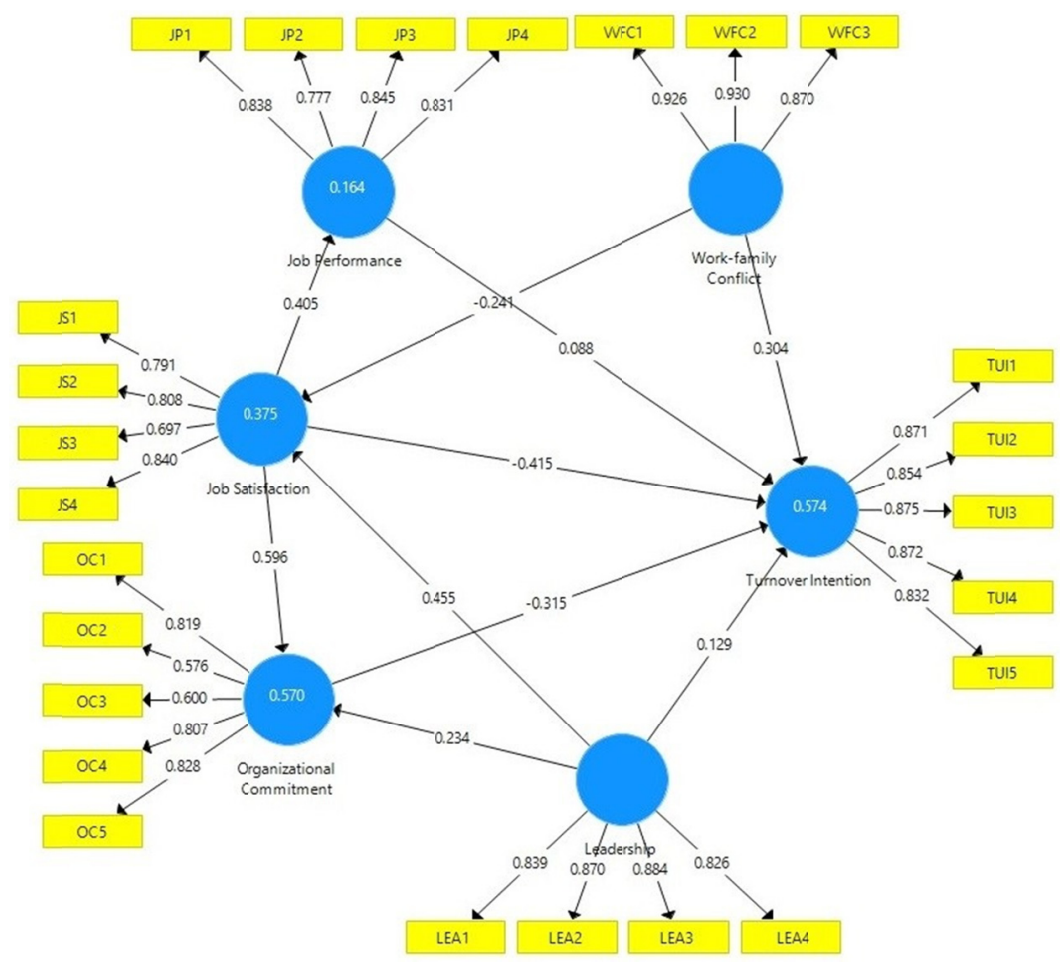

Figure 2. Model results 
H1 stated that job satisfaction has a significant negative effect on workers' turnover intention. As is evident from Table 8, the path coefficient between the two variables is -.415 , and the $p$-value is .023 . Thus, the negative relationship between job satisfaction and turnover intention is significant. Moreover, the results of the correlation test indicated a significant negative association between job satisfaction and turnover intention $(r=-.729, p$ $<.001$ ), as shown in Table 2. Consequently, hypothesis $\mathrm{H} 1$ is supported. The same result was also found from many different scholars who all concluded that manufacturing workers are satisfied with their jobs, leading to a decrease in turnover intention (Hellman,1997; Lu, While \& Barriball 2005; Hayes et al., 2006).

Job satisfaction showed positive significant correlations with job performance $(r=.503, p<.001)$. This result implies that manufacturing workers who have higher job satisfaction also have higher job performance. However, the results of testing the SEM indicated an insignificant influence of these two variables $(\beta=.405, p=.079)$, as shown in Table 8. Therefore, hypothesis $\mathrm{H} 2$ was rejected.

$\mathrm{H} 3$ stated that job satisfaction has a significant positive effect on workers' organizational commitment. As is evident from Table 8, the path coefficient between the two variables is 0.596 , and the $p$-value is .000 . Furthermore, the results of the correlation test indicated a significant positive association between work-family conflict and turnover intention $(r=.789, p<.001)$. Thus, hypothesis H3 was accepted.

$\mathrm{H} 4$ predicted that organizational commitment has a significant negative effect on turnover intention. As is evident from Table 8 , the path coefficient between the two variables is -.315 , and the $p$-value is .000 . This result illustrates the significant negative influence of organizational commitment on turnover intention. Additionally, a significant negative relationship between organizational commitment and turnover intention $(r=-.697, p<.001)$ was presented in the correlation test, as shown in Table 2. Accordingly, $\mathrm{H} 4$ was supported.

The results in Table 2 show that there is no significant association between job performance and turnover intention $(r=-.351, p>.05)$. Moreover, the results of testing the SEM indicated an insignificant influence of these two variables $(\beta=.088, p>.05)$, as is depicted in Table 8 . Therefore, hypothesis $\mathrm{H} 5$ was rejected.

The results in Table 2 show that there is a significant association between leadership and turnover intention $(r=$ $-.475, p<.001)$. However, the results of testing the SEM indicate an insignificant influence of these two variables $(\beta=.129, p=.450)$, as is shown in Table 8 . Therefore, hypothesis H6 was rejected.

$\mathrm{H} 7$ stated that leadership has a significant positive effect on workers' job satisfaction. As is evident from Table 8, the path coefficient between the two variables is .455, and the $p$-value is .001. Furthermore, leadership showed positive correlations with job satisfaction $(r=.641, p<.001)$, as is shown in Table 2. Thus, the positive relationship between leadership and job satisfaction is significant, and hypothesis $\mathrm{H} 7$ is supported.

The results in Table 2 show that there is a significant, positive association between leadership and organizational commitment $(r=.628, p<.001)$. However, the results of testing the SEM indicate an insignificant influence of these two variables $(\beta=.234, p=.067)$, as is shown in Table 8 . Therefore, hypothesis $\mathrm{H} 8$ was rejected.

H9 stated that work-family conflict is a significant predictor of manufacturing workers' turnover intentions. As is evident from Table 8, the path coefficient between the two variables is .304, and the $p$-value is .047. Additionally, the results of the correlation test indicate a significant positive association between work-family conflict and turnover intention $(r=.602, p<.001)$. Thus, hypothesis $\mathrm{H} 9$ was accepted.

H10 stated that work-family conflict has a significant negative effect on job satisfaction. As is evident from Table 8, the results of investigating the SEM present a significant, negative effect of work-family conflict on job satisfaction $(\beta=-.241, p=.003)$. Furthermore, the results of the correlation test indicate a significant positive association between work-family conflict and turnover intention $(r=-.541, p<.001)$. Thus, hypothesis H10 was accepted.

\section{Discussion and Conclusion}

\subsection{Summary of Findings and Implications}

The primary goal of this study was to investigate the relationships among job satisfaction, organizational commitment, leadership, work-family conflict, job performance and turnover intention in a sample of Tennessee manufacturing workers. Both positive and negative findings are summarized below, and their theoretical and practical implications are briefly discussed as follows.

Many different measuring instruments for turnover intention have been used in past studies. However, the mean scores and the percentages of the high perception method could provide a direct reference for potential turnover behaviors. The score for the five items for turnover intention ranged from 2.18 to 2.51, and the mean score of the overall perception of turnover intention was 2.37 , which is very close to the five-range-scale 2 - disagree. The 
participants who chose 1 - strongly disagree and 2 - disagree were considered to have the high turnover intention; in contrast, those who chose 5 - strongly agree and 4 - agree were considered to have low turnover intention. Based on the frequency results, the percentage of low turnover intention participants for each item of turnover intention were $58.0 \%, 58.0 \%, 57.2 \%, 63.0 \%$ and $69.6 \%$; however, the percentage of high turnover intention participants for each item of turnover intention was $19.6 \%, 19.6 \%, 21.0 \%, 10.9 \%$ and 10.9 . Although this implies that the turnover intention of manufacturing workers was much smaller than that of other industries, such as IT workers or health workers, more attention should be paid to manufacturing workers in Tennessee to reduce their turnover intention.

The hypothesis test results show that job satisfaction and organizational commitment have a significant negative effect on turnover intention, but work-family conflict has a significant positive effect on turnover intention. This result illustrates that job satisfaction, organizational commitment, and work-family conflict are the determinants of turnover intention for manufacturing workers.

The results of our model indicate that job satisfaction has a significant negative impact on turnover intention and support the work of Hellman and his colleagues (Hellman, 1997) who also concluded that there is a significant negative relationship between job satisfaction and turnover intention. This result offers an explanation for why a decrease in turnover intention occurs when workers are satisfied with their jobs (Lu, While \& Barriball, 2005) or why an employee who develops a positive attitude toward his/her job and feels more satisfied with his/her job will have more intent to stay with his/her organization (Chen, 2001). However, some scholars argue that job satisfaction has no significant net influence on turnover intention and only serves as a mediating variable between the other variables and turnover intention (Price \& Mueller, 1981). The significant positive relationship between job satisfaction and organizational commitment illustrates that greater job satisfaction produces greater organizational commitment. Similar conclusions were drawn by Williams and Hazer who reported that the absence of job satisfaction, such as achievement, recognition or job content, often leads to the reduction of organizational commitment. This implies that manufacturing organizations should begin to work toward developing a deeper understanding of job satisfaction by creating strategies that will contribute to the improvement of the conditions of employment, which will have a positive influence on the commitment of their workers. Management should first determine the particular aspects of the job that contribute to satisfaction or dissatisfaction among manufacturing workers, which will enable them to determine the areas that require improvement.

Consistent with many previous studies, there is a significant negative relationship between organizational commitment and turnover intention (Nipius, 2012). It was confirmed that employees' intentions to stay with an organization increase when they feel happy at work and a sense of commitment develops. Allen and Meyer (Allen \& Meyer, 1990) proposed the three-component model, which contains effective, continuous and normative components, and proved that organizational commitment is negatively related to intention to leave. Some studies showed the insignificant effect of organizational commitment on turnover intention due to the poor response rates and biases of the respondents (Iqbal, Ehsan, Rizwan, \& Noreen, 2012). These authors argued that organizational commitment no longer plays a role in decreasing turnover intention if an employee is presented with the best opportunities or required working conditions. Therefore, these results suggest that management should regard lower levels of organizational commitment as a method of coping with an unpleasant emotional state and as an attempt by workers to reduce their contributions to the organization in order to restore an equitable exchange relationship. It is also recommended that management apply relevant remedies in order to prevent withdrawal behaviors such as turnover intention.

Leadership, one of the variables given considerable attention in the literature review as a significant determinant and intervening variable, was found to have a significant net influence on job satisfaction and organizational commitment but no significant net influence on turnover intention. This finding is consistent with the finding of a previous investigation on job satisfaction that a lack of effective leadership skills negatively affected employee job satisfaction. Thus, manufacturing workers' perceptions of leadership skills have a significant positive impact on their job satisfaction and organizational commitment. Surprisingly, some previous research, such as the study conducted on assistant coaches in the USA by Wells and Peachey (Wells \& Peachey, 2011), proved a significant negative relationship between leadership behavior and turnover intention, but our results showed a nonsignificant relationship between these two variables. Thus, this hypothesis is rejected because leadership is not an important factor in manufacturing workers' turnover intention. However, job satisfaction and organizational commitment are both very important mediating variables for leadership and turnover intention.

The causal model also showed that work-family conflict negatively influenced job satisfaction but positively affected turnover intention, which has also been proven in many other studies. Lu et al. (Lu, Hu, Huang, Zhuang, 
\& Guo, 2017) believed that there is a positive relationship between work characteristics (night shifts, minimal control over work hours or unpredictable scheduling requirements) and work-family conflict and a positively relationship with turnover intention. The results also showed that work-family conflict has a positive impact on turnover intention with job satisfaction as a mediator. Hence, manufacturing workers who suffer higher work-family conflict also have lower job satisfaction and higher turnover intention. Thus, the present findings provide several important practical implications for management regarding work-family conflict. The first recommendation for reducing work-family conflict is that manufacturing organizations should offer formal work-family policies to their workers, such as flexible work schedules. Second, manufacturing organizations should provide adequate support for their employees. For example, management should provide adequate support when the employee is addressing family obligations, such as going to a child's football game or being present for a spouse who has a medical issue.

Unexpectedly, there is no significant relationship between job satisfaction and job performance or job performance and turnover intention. A study conducted by Carraher and Buckley (Carraher \& Buckley, 2008) concluded that nurses who had poor job performance exhibited symptoms of intention to quit, such as searching for a new job or being absent from work. However, in our study, job performance was not a significant predictor of turnover intention.

\subsection{Limitation}

There is no doubt that our study had several limitations. The main limitation of this study was that the results had limited generalizability since all the variables were measured with data collected from manufacturing companies with only 138 valid datasets, which may limit the external validity. Nonetheless, the results of our study did provide insight into the reasons why manufacturing workers exhibited turnover intentions and into the predictor of the turnover intentions. The second limitation of this study was that our study used a self-reported questionnaire, which may produce a lack of control over respondents or a significant threat of common method variance.

\subsection{Conclusion}

In this study of manufacturing companies, we tested the relationship among job satisfaction, organizational commitment, leadership, work-family conflict, job performance, and turnover intention. The results concluded that the turnover intention of manufacturing workers was significantly associated with job satisfaction, organizational commitment, and work-family conflict. Leadership was also significantly related to turnover intention, but its effects on turnover intention were fully mediated by job satisfaction and organizational commitment. Job performance was not a critical factor of turnover intention for manufacturing workers. Hence, our research suggested that the policymakers and administrators in the manufacturing company should develop appropriate policies that focus on job satisfaction, organizational commitment and work-family conflict to achieve the objective of reducing turnover intention. Measures should be implemented to enhance workers' job satisfaction and organizational commitment, balance work-family conflict, and improve the leadership style.

\section{References}

Ahuja, M., Chudoba, K., Kacmar, C., McKnight, D., \& George, J. (2007). IT road warriors: balancing work-family conflict, job autonomy, and work overload to mitigate turnover intentions. MIS Quarterly, 31(1), 1-17. https://doi.org/10.2307/25148778

Allen, D. G., Bryant, P. C., \& Vardaman, J. M. (2010). Retaining talent: replacing misconceptions with evidence-based strategies. Academy of Management Perspectives, 24(2), 48-64. https://doi.org/10.5465/amp.24.2.48

Allen, N. J., \& Meyer, J. P. (1990). Organizational socialization tactics: a longitudinal analysis of links to the newcomer's commitment and role orientation. Academy of Management Journal, 33(4), 847-858. https://doi.org/10.5465/256294

Armstrong, G. S., Atkin-Plunk, C. A., \& Wells, J. (2015). The relationship between work-family conflict, correctional officer job stress, and job satisfaction. Criminal Justice and Behavior, 42(10), 1066-1082. https://doi.org/10.1177/0093854815582221

Barclay, D., Higgins, C., and Thompson, R. (1995). The partial least squares (pls) approach to causal modeling: Personal computer adoption and use as an illustration. Technology studies, 2(2), 285-309.
Bares,
A. (2016).
2016
Turnover
Rates
by
Industry. http://www.compensationforce.com/2017/04/2016-turnover-rates-by-industry.html 
Bass, B. M. (1990). From transactional to transformational leadership: learning to share the vision. Organizational Dynamics, 18(3), 19-32. https://doi.org/10.1016/0090-2616(90)90061-S

Becker, G. S. (1960). An economic analysis of fertility. In Universities-National Bureau Committee for Economic Research, Demographic and Economic Change in Developed Countries. Princeton: Princeton University Press

Blomme, R. J., Rheede, A. V., \& Tromp, D. M. (2010). Work-family conflict as a cause for turnover intentions in the hospitality industry. Tourism and Hospitality Research, 10(4), 269-285. https://doi.org/10.1057/thr.2010.15

Bright, L. (2008). Does public service motivation really make a difference on the job satisfaction and turnover intentions of public employees? The American Review of Public Administration, 38(2), 149-166. https://doi.org/10.1177/0275074008317248

Bycio, P., Hackett, R. D., \& Allen, J. S. (1995). Further assessments of Bass's (1985) conceptualization of transactional and transformational leadership. Journal of Applied Psychology, 80(4), 468-478. http://dx.doi.org/10.1037/0021-9010.80.4.468

Carraher, S. M. \& Buckley, M. R. (2008). Attitudes towards benefits and behavioral intentions and their relationship to absenteeism, performance and turnover among nurses. Academy of Health Care Management Journal, 4(2), 89-109.

Chao, M. C., Jou, R. C., Liao, C. C., \& Kuo, C. W. (2015). Workplace stress, job satisfaction, job performance, and turnover intention of health care workers in rural Taiwan. Asia Pacific Journal of Public Health, 27(2), 1827-1836. https://doi.org/10.1177/1010539513506604

Chen, Z. (2001). Further investigation of the outcomes of loyalty to supervisor: job satisfaction and intention to stay. Journal of Managerial Psychology, 16(8), 650-660. https://doi.org/10.1108/EUM0000000006305

Chieh Lu, A. C., \& Gursoy, D. (2016). Impact of job burnout on satisfaction and turnover intention: do generational differences matter? Journal of Hospitality \& Tourism Research, 40(2), 210-235. https://doi.org/10.1177/1096348013495696

Cohen, J. (1988). Statistical power analysis for the behavioral sciences. Mahwah, NJ: Lawrence Erlbaum.

Cortese, C. G., Colombo, L., \& Ghislieri, C. (2010). Determinants of nurses' job satisfaction: The role of work-family conflict, job demand, emotional charge and social support. Journal of Nursing Management, 18(1), 35-43. https://doi.org/10.1111/j.1365-2834.2009.01064.x.

Cropanzano, R., Rupp, D. E., \& Byrne, Z. S. (2003). The relationship of emotional exhaustion to work attitudes, job performance, and organizational citizenship behaviors. Journal of Applied Psychology, 88(1), 160-169. http://dx.doi.org/10.1037/0021-9010.88.1.160

Dale, K., \& Fox, M. (2008). Leadership style and organizational commitment: mediating effect of role stress. Journal of Managerial Issues, 20(1), 109-130. http://www.jstor.org/stable/40604597

DeConinck, J. B., \& Stilwell, C. D. (2004). Incorporating organizational justice, role states, pay satisfaction and supervisor in a model of turnover intention. Journal Business Reviews, 57(3), 225-231. https://doi.org/10.1016/S0148-2963(02)00289-8

Geisser, S. (1974). A predictive approach to the random effect model. Biometrika, 61(1), 101-107. https://doi.org/10.2307/2334290

Glissmeyer, M. (2012). Role conflict, role ambiguity and intention to quit the organization: the case of law enforcement officers. Journal of Management, 26(6), 1113-1131.

Greenhaus, J., \& Beutell, N. (1985). Sources of conflict between work and family roles. The Academy of Management Review, 10(1), 76-88. http://www.jstor.org/stable/258214

Gregson T. (1992). An investigation of the causal ordering of job satisfaction and organizational commitment in turnover models in accounting. Behavioral Research in Accounting, 4, 80-95.

Griffeth, R. W., Hom, P. W., \& Gaertner, S. (2000). A meta-analysis of antecedents and correlates of employee turnover: update, moderator tests, and research implications for the next millennium. Journal of Management, 26, 463-488. https://doi.org/10.1177/014920630002600305

Gu, S. T., Huang, Q. M., Chen, Z. Q., Wang, M. Y., Chen, K., \& Cui, Y. (2006). Relationship between job satisfaction and turnover intention among physicians from three grade hospitals. Chinese Journal of 
Hospital Administration, 9, 586-589.

Hancock, J. I., Allen, D. G., Bosco, F. A., McDaniel, K. R., \& Pierce, C. A. (2013). Meta-analytic review of employee turnover as a predictor of firm performance. Journal of Management, 39(3), 573-603. https://doi.org/10.1177/0149206311424943

Hayes, L. J., O’Brien-Pallas, L., Duffield, C., Shamian, J., Buchan, J., Hughes, F., Laschinger, H. K. S., North, N., \& Stone, P. W. (2006). Nurse turnover: a literature review. International Journal of Nursing Studies, 43, 237-263. https://doi.org/ 10.1016/j.ijnurstu.2005.02.007

Hellman, C. M. (1997). Job satisfaction and intent to leave. The Journal of Social Psychology, 137(6), 677-689. https://doi.org/10.1080/00224549709595491

Hinshaw A. S., Smeltzer C., \& Atwood J. R. (1987). Innovative retention strategies for nursing staff. Journal of Nursing Administration, 17(6), 8-16.

Hom, P. W. (2011). Organizational exit. in S. Zedeck (Ed.), Handbook of industrial/organizational psychology. Washington, Dc: American Psychological Association.

Huysamen, G. K. (1994). Methodology for the social and behavioral sciences. Halfway House: Southern.

Iqbal, S., Ehsan, S., Rizwan, M. \& Noreen, M. (2012). The impact of organizational commitment, job satisfaction, job stress and leadership support on turnover intention in educational institutes. International Journal of Human Resource Studies, 4(2), 181-195. https://doi.org/10.5296/ijhrs.v4i2.5906

Jamal, M. (1997). Job stress, satisfaction, and mental health: An empirical examination of self-employed and non-self-employed Canadians. Journal of Small Business Management, 35(4), 48-57. https://login.proxy.lib.utk.edu:443/login?

Jaros, S. J. (2007). The Meyer and Allen model of organizational commitment: measurement issues. Journal of Organizational Behavior, 6(4), 7-25.

Joseph, D., Kok-Yee, N., Koh, C., \& Ang, S., (2007). Turnover of Information Technology Professionals: A Narrative Review, Meta-Analytic Structural Equation Modeling, and Model Development. MIS Quarterly, 31(3), 547-577.

Judge, T. A., \& Bono, J. E. (2001). Relationship of core self-evaluations traits--self-esteem, generalized self-efficacy, locus of control, and emotional stability--with job satisfaction and job performance: a meta-analysis. The Journal of applied psychology, 86(1), 80-92.

Karatepe, O. M., \& Baddar, L. (2006). An empirical study of the selected consequences of frontline employees' work-family conflict and family-work conflict. Tourism Management, 27(5), 1017-1028. https://doi.org/10.1016/j.tourman.2005.10.024

Koopmans L, Bernaards C., Hildebrandt V., Buuren S, Van der Beek A. J., \& De Vet H. C. W. (2012). Development of an individual work performance questionnaire. International Journal of Productivity and Performance Management, 62(1), 6-28. https://doi.org/10.1108/17410401311285273

Lambert, E., \& Hogan, N. (2009). The importance job satisfaction and organizational commitment in shaping turnover intent: a test of a causal model. Criminal Justice Review, 34(1), 96-118. https://doi.org/10.1177/0734016808324230

Lee, K. S., \& Gao, T. (2005). Studying organizational commitment with the OCQ in the Korean retail context: its dimensionality and relationships with satisfaction and work outcomes. International Review of Retail, Distribution band Consumer Research, 15(4), 375-399. https://doi.org/10.1080/09593960500197495

Lu, H., While, A. E., \& Barriball, K. L. (2005). Job satisfaction among nurses: a literature review. International Journal of Nursing Studies, 42(2), 211-227. https://doi.org/10.1016/j.ijnurstu.2004.09.003

Lu, Y., Hu, X. M., Huang, X. L., Zhuang, X. D., \& Guo, P. (2017). The relationship between job satisfaction, work stress, work-family conflict, and turnover intention among physicians in Guangdong, China: a cross-sectional study. Journal BMJ Open, 7(5), 1-12. https://doi.org/10.1136/bmjopen-2016-014894.

Martin, R., \& Epitropaki, O. (2001). Role of organizational identification on implicit leadership theories (ilts), transformational leadership and work attitudes. Group Processes \& Intergroup Relations, 4(3), $247-262$. https://doi.org/10.1177/1368430201004003005

Meyer, J. P., Stanley, D. J., Herscovitch, L., \& Topolnytsky, L. (2002). Affective, continuance, and normative commitment to the organization: A meta-analysis of antecedents, correlates, and consequences. Journal of 
Vocational Behavior, 61(1), 20-52. https://doi.org/10.1006/jvbe.2001.1842

Michael J. M., \& Eric K. K. (2013). Do job satisfaction and commitment to the organization matter when it comes to retaining employees? Journal of Extension, 51(4).

McCutcheon A. S., Doran D., Evans M., McGillis H. L., \& Pringle D. (2009). Effects of leadership and span of control on nurses' job satisfaction and patient satisfaction. Canadian Journal of Nursing Leadership, 22(3), 48-67.

Muchinsky P. M., \& Morrow P. C. (1980). A multidisciplinary model of voluntary employee turnover. Journal of Vocational Behavior, 17(3), 263-290. https://doi.org/10.1016/0001-8791(80)90022-6

Netemeyer R. G., Boles J. S., \& McMurrian R. (1996). Development and validation of work-family conflict and family-work conflict scales. Journal of Applied Psychology, 81(4), 400-410.

Nipius, T. P. M. (2012). The influence of high commitment HR system on turnover intention at the individual level: a critical view. (Master's thesis, Tilburg University, Netherlands).

Omar, K., Anuar, M. M., Majid, A. H. A., \& Johari, H. (2012). Organizational Commitment and Intention to Leave Among Nurses in Malaysian Public Hospitals. International Journal of Business and Social Science, 3(16), 194-199.

Ponnu, C. H., \& Chuah, C. C. (2010). Organizational commitment, organizational justice and employee turnover in Malaysia. African Journal of Business Management, 4(13), 2676-2692.

Poon, J. M. L. (2004). Effects of performance appraisal politics on job satisfaction and turnover intention. Personnel Review, 33(3), 322-334. https://doi.org/10.1108/00483480410528850

Podsakoff, N. P., Lepine, J. A., \& Lepine, M. A. (2007). Differential challenge stressor-hindrance stressor relationships with job attitudes, turnover intentions, turnover and withdrawal behavior: A meta-analysis. Journal of Applied Psychology, 92(2), 438-454. https://doi.org/10.1037/0021-9010.92.2.438

Post, C., DiTomaso, N., Farris, G. F., \& Cordero, R. (2009). Work-family conflict and turnover intentions among scientists and engineers working in R\&D. Journal of Business and Psychology, 24(1), 19-32. http://dx.doi.org/10.1007/s10869-009-9089-1

Price, J. L., \& Mueller, C. W. (1981). A causal model of turnover for nurses. Academy of Management, 24(3), 543-564. https://www.jstor.org/stable/255574

Raimonda A., \& Modesta M. (2016). Leadership style and job satisfaction in higher education institutions. International Journal of Educational Management, $30(1), \quad$ 140-164. https://doi.org/10.1108/IJEM-08-2014-0106

Ryan D. Z., \& Todd C. D. (2009). The impact of job performance on employee turnover intentions and the voluntary turnover process: A meta-analysis and path model. Personnel Review, 38(2) 142-158. https://doi.org/10.1108/00483480910931316

Schwepker, H. C. (1999). the relationship between ethical conflict, organizational commitment and turnover intentions in the salesforce. Journal of Personal Selling and Sales Management, 19(1), 43-49.

Shaw, J. D., Gupta, N., \& Delery, J. E. (2005). Alternative conceptualizations of the relationship between voluntary turnover and organizational performance. Academy of Management Journal, 48(1), 50-60. https://doi.org/10.5465/amj.2005.15993112

Spector P. E. (1994). Job Satisfaction Survey. Tampa, FL: Department of Psychology, University of South Florida.

Somers, M. J. (1993). A test of the relationship between affective and continuance commitment using non-recursive models. Journal of Occupational and Organizational Psychology, 66(2), 185-192. https://doi.org/10.1111/j.2044-8325.1993.tb00528.x

Stone, M. (1974). Cross-validatory choice and assessment of statistical predictions. journal of the royal statistical society. Series B (Methodological), 36(2), 111-147. http://www.jstor.org/stable/2984809

Tabachnick B. G. \& Fidell L.S. (2007). Using multivariate statistics. Fifth Edition. Pearson Education Inc.

Tett, R. P., \& Meyer, J. P. (1993). Job satisfaction, organizational commitment, turnover intention, and turnover: Path analyses based on meta-analytic findings. Personnel Psychology, 46(2), 259-293. https://doi.org/10.1111/j.1744-6570.1993.tb00874.x 
Ton, Z., \& Huckman, R. S. (2008). Managing the impact of employee turnover on performance: The role of process conformance. Organization Science, 19(1), 56-68.

Wells J. E. \& Peachey, J.W. (2011). Turnover intentions: Do leadership behaviors and satisfaction with the leader matter? Team Performance Management, 17(1/2), 23-40. https://doi.org/10.1108/13527591111114693

Wu, X., \& Polsaram, P. (2013). Factor influencing employee turnover intention: the case of retail industry in Bangkok, Thailand. Journal of Finance, Investment, Marketing, Business Management, 3(3), 127-142.

\section{Copyrights}

Copyright for this article is retained by the author(s), with first publication rights granted to the journal.

This is an open-access article distributed under the terms and conditions of the Creative Commons Attribution license (http://creativecommons.org/licenses/by/4.0/). 